\title{
First data on reproduction and growth of Buenia affinis Iljin, 1930 (Gobiidae) in the northern Adriatic Sea
}

\author{
MARCELO KOVAČIĆ ${ }^{1}$ and MARIO LA MESA ${ }^{2}$ \\ ${ }^{1}$ Prirodoslovni muzej Rijeka, Lorenzov prolaz 1, HR-51000 Rijeka, Croatia. E-mail: marcelo@ prirodoslovni.com \\ ${ }^{2}$ Istituto di Scienze Marine (CNR-ISMAR), UOS di Ancona, Largo Fiera della Pesca 1, 60125 Ancona, Italy.
}

\begin{abstract}
SUMMARY: De Buen's goby, Buenia affinis, is a very small Mediterranean goby (38.8 mm TL) inhabiting sandy infralittoral bottoms and known only from a few published records. Some aspects of reproduction and growth of $B$. affinis were investigated from a population collected in the Kvarner area (north-eastern Adriatic Sea). Sampling was carried out by SCUBA diving between May 2003 and April 2004. The sex ratio did not differ significantly. The estimated length at sexual maturity was 26.1 and $27.4 \mathrm{~mm}$ for females and males, respectively. The spawning season extended from February to July. The absolute fecundity (F) ranged from 457 to 714 eggs per individual (mean $\pm \mathrm{SE}, 556 \pm 25$ ). Based on the length frequency distribution analysis throughout the year and seasonal growth bands on sagittal otoliths, $B$. affinis was assumed to be an annual species.
\end{abstract}

Keywords: Gobiidae, Buenia affinis, reproduction, growth, sex ratio.

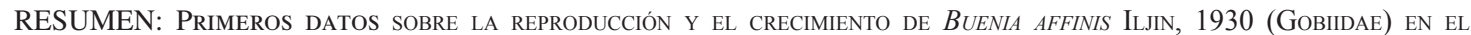
ADRIÁtico NORTE. - El gobio de De Buen, Buenia affinis, es un minúsculo góbido mediterráneo ( $38.8 \mathrm{~mm}$ LT) que habita fondos arenosos litorales y del cual sólo hay unas pocas citas publicadas. Hemos investigado algunos aspectos de la reproducción y el crecimiento de $B$. affinis a partir de muestras de una población del área de Kvaner (Adriático nororiental). El muestreo se realizó mediante buceo con escafandra autónoma entre mayo de 2003 y abril de 2004 . El sex ratio no presentó diferencias significativas. La talla estimada de madurez sexual fue de $26.1 \mathrm{~mm}$ para las hembras y de $27.4 \mathrm{~mm}$ para los machos. La época de puesta se extendió de febrero a julio. El rango de fecundidad absoluta (F) fue de 457 a 714 huevos por individuo (media $\pm \mathrm{SE}, 556 \pm \mathrm{SE}$ ). En base al análisis de la distribución de la frecuencia de tallas a lo largo del año y a las bandas de crecimiento de los otolitos sagitales, B. affinis parece ser una especie anual.

Palabras clave: Gobiidae, Buenia affinis, reproducción, crecimiento, sex ratio.

\section{INTRODUCTION}

The Gobiidae, comprising 93 species, is numerically the dominant fish family in the northeastern Atlantic, Mediterranean and Black Seas (Kovačić and Patzner, 2010). However, the biology of most gobiid species inhabiting these areas is largely unknown or poorly known. Data on growth and reproduction are currently available for only $1 / 3$ and $1 / 2$ of gobies, respectively (Kovačić, 2001). Gobies are generally small-sized fishes, and about 1/4 of the northeastern
Atlantic, Mediterranean and Black Sea species are very small, not reaching $5 \mathrm{~cm}$ TL (Kovačić and Patzner, 2010).

The small size in teleosts provides advantages in efficiency of feeding on small prey and in colonization and exploitation of particular habitats (Miller, 1979, 1996). Indeed, the very small gobies of the northeastern Atlantic, Mediterranean and Black Seas are present in epibenthic, cryptobenthic and nektonic ecotopes (Miller, 1979), including both pelagic and hyperbenthic species. Body miniaturization, or the evolution of 
extremely small adult body size, characterizes some pelagic gobies, which exhibit larval morphological traits through reduction and structural simplification. In these species, the pelagic lifestyle increases the risk of predation also for adults, which is compensated by an early attainment of sexual maturity through progenesis (Miller, 1984). Unfortunately, due to their very small body size, the collection and handling of such gobies are rather difficult, so knowledge of their life history patterns is generally limited. The biology of very small benthic gobies is even less known than that of nektonic species, and is restricted mostly to the reproductive traits of the epibenthic Pomatoschistus species (Miller, 1986; Rogers, 1989; Fouda et al., 1993; Pampoulie and Bouchereau, 1996; Bouchereau and Guelorget, 1998; Pampoulie et al., 2000; Mazzoldi and Rasotto, 2001; Bouchereau, 2002).

B. affinis is a very small Mediterranean goby, attaining a maximum size of $38.8 \mathrm{~mm}$ TL (Kovačić, 2002, present data). It is epibenthic, inhabiting sandy bottoms between 3 and $25 \mathrm{~m}$ depth (Kovačić, 2002). $B$. affinis is known only from a few published records. The positive records were only those from Naples, Italy (Sanzo, 1911), from the Kvarner area, Croatia (Kovačić, 2002), and from Banyuls, France, where it was misidentified as Buenia jeffreysii (Günther, 1867) (Zander, 1982; Kovačić and Patzner, 2009). Two other doubtful records were reported from the Aegean Sea on postlarval specimens (Fage, 1918) and from Nice and Genoa (Miller, 1986). Until now, the available data on B. affinis concerned body morphology (morphometrics, meristics, papillae counts, coloration), distribution (habitat, biocenosis, fish assemblage) and feeding habits (Zander, 1982; Zander and Berg, 1984 probably also misidentified as Buenia jeffreysii; Kovačić, 2002; Kovačić and La Mesa, 2008).

The aim of this study is to provide the first data on reproduction and growth of $B$. affinis, including sex ratio, length at sexual maturity, annual cycle of gonad development, spawning period, relationship of reproductive cycle and liver storage, fecundity, growth rate and recruitment.

\section{MATERIALS AND METHODS}

Two hundred and forty specimens of B. affinis were obtained from the locality Oštro in the Rijeka Bay (Fig. $1)$, in the northern part of the Kvarner area $\left(45^{\circ} 16^{\prime} \mathrm{N}\right.$, $14^{\circ} 34^{\prime} \mathrm{E}$ ) from May 2003 to April 2004. All fish were collected on sandy bottoms between 5 and $10 \mathrm{~m}$ depth, using a hand net and quinaldine anaesthetic during SCUBA dives. On a monthly basis, twenty specimens were collected in a single dive of approximately 30 minutes and the water temperature was measured on the sea bed during the dives. All specimens were killed by over-anaesthetization with quinaldine and stored in $65 \%$ ethanol solution.

In the laboratory, total length (TL) of each individual was measured to the nearest $0.1 \mathrm{~mm}$ and wet
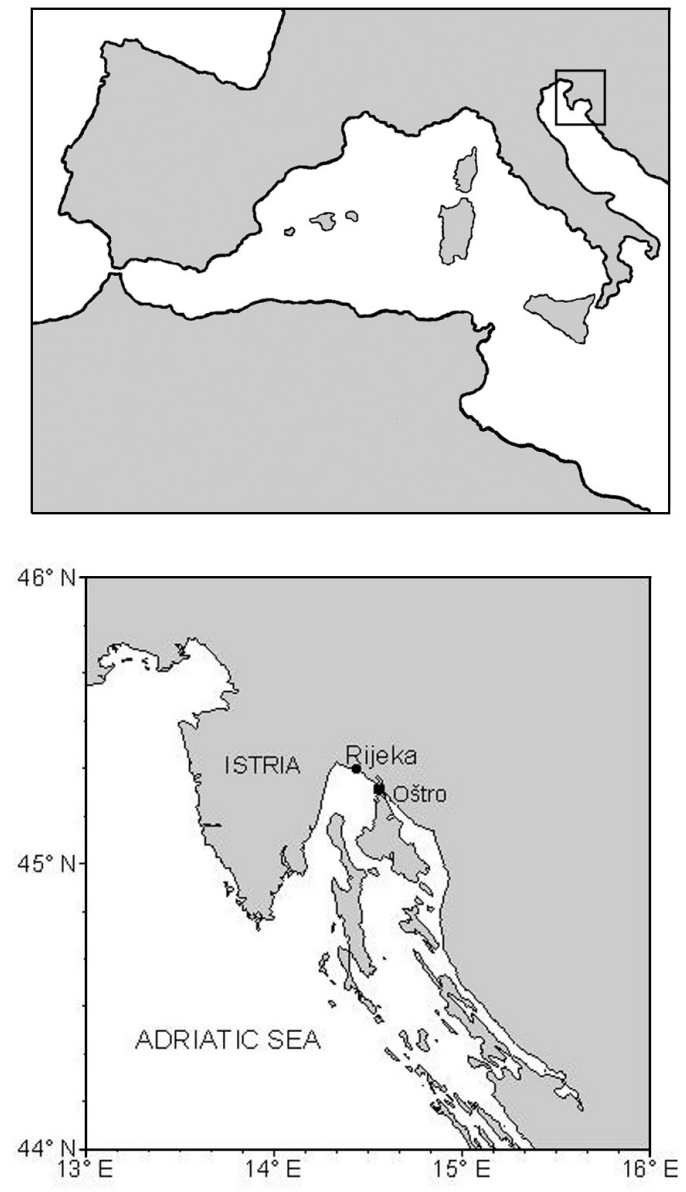

FIG. 1. - Map of the western Mediterranean and Adriatic Sea showing the Kvarner area and a detail map of the Kvarner area with the sampling location of Buenia affinis at Oštro.

mass was weighed to the nearest $0.001 \mathrm{~g}$ after blotting dry on absorbent paper. All fish were dissected under a stereomicroscope and gut, liver and gonads were removed. Sex was recorded on the basis of the gross gonad morphology. The gonads were macroscopically staged according to a five-point scale of maturity proposed for gobies (Miller, 1961), using morphology, coloration, relative size and, in females, egg size: I, immature; II, developing virgin or recovering spent; III, ripening (for females IIIa = early ripening and IIIb = late ripening); IV, ripe; and V, spent. Egg size was measured as maximum diameter using a micrometric scale. The wet mass of gonads and liver was obtained to the nearest $0.01 \mathrm{mg}$ after blotting dry on absorbent paper. In males the whole testicular apparatus (testes and seminal vesicles) was weighed as gonad mass. Furthermore, the seminal vesicles were weighed separately (Kovačić, 2001). Due to the overall small size of the species, the wet mass of seminal vesicles or even the whole testicular apparatus of immature males was close to the resolution limit of the balance $(0.01 \mathrm{mg})$. All weighed values below $0.05 \mathrm{mg}$ had low accuracy and precision, so they were rounded to $0.025 \mathrm{mg}$. However, this estimation had a negligible influence on re- 
lationships among monthly gonad indices, as the adult gonad and seminal vesicles masses were much higher.

Potential or absolute fecundity (F), defined as the number of eggs found in females prior to the next spawning period, was calculated by counting all the ripe eggs found in the ovaries. Relative fecundity (Fr), namely the number of eggs per unit of body weight (Kartas and Quignard, 1984), was also calculated. The relationship between fish size and absolute/relative fecundity was assessed by applying linear regression analysis on log-transformed data.

Sex ratio was calculated and the significance of deviation from the 1:1 null hypothesis was tested by the $\chi^{2}$ test (Sokal and Rohlf, 1995). The length at sexual maturity was estimated by the proportion of specimens at stages II-V vs immature specimens (i.e. specimens without signs of gonad development, stage I). The length at sexual maturity, defined as the length at which $50 \%$ of fish reach sexual maturity, was estimated by means of a logistic function fitted to the proportion of the specimens pooled in $5 \mathrm{~mm}$ length classes (L). The quasi-Newton algorithm for non-linear least square estimation of function parameters was applied to data according to the following equation: $\mathrm{P}_{\mathrm{L}}=(1+$

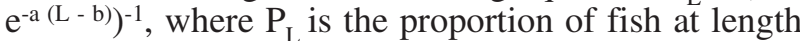
$\mathrm{L}$, $\mathrm{a}$ and $\mathrm{b}$ are estimated parameters, and $\mathrm{a}$ is the slope of the curve. For $b=L, P_{L}=0.5$, i.e. $b$ is equal to the length when the proportion of fish is $0.5\left(\mathrm{~L}_{50}\right)$.

The annual cycle of gonad development was investigated using maturity stages as in Miller (1961), and calculating gonadosomatic index (GSI= gonad wet mass $\mathrm{x} 100 \mathrm{x}$ body wet mass $^{-1}$ ) and seminal-vesicle-somatic index $($ SVSI $=$ seminal vesicle wet mass $\mathrm{x} 100 \mathrm{x}$ body wet mass $^{-1}$ ) (Patzner et al., 1991) on monthly samples. The hepatosomatic index (HSI) was calculated as HSI = liver wet mass $\mathrm{x} 100 \mathrm{x}$ body wet mass $^{-1}$ (Fouda et al., 1993), as a measure proportional to energy reserves stored in this organ. All indices were compared on a monthly basis and the HSI was compared between sexes. Homogeneity of variance and normality were tested with Levene's and Shapiro-Wilk test, respectively. Monthly trends of GSI and SVSI were compared using the non-parametric Kruskal-Wallis test, since the assumptions of normality and homogeneity were not met after arc-sine or logarithmic transformation (Sokal and Rohlf, 1995). Two-way ANOVA was used to compare arcsine-transformed HSI across months and between sexes as fixed factors. Non-linear estimate of logistic function parameters for length at sexual maturity was calculated using Statistica 5.1. Descriptive statistics are reported as mean \pm standard error. Other data analyses for reproduction were carried out using the MS Excel and SPSS software packages.

To estimate age and growth rate, sagittal otoliths were initially removed from each specimen. However, after some trials, fish ageing by microincrement counts on otolith sections was not possible due to the rather unclear and confused pattern. Sagittal otoliths were subsequently viewed under a stereomicroscope to
TABLE 1. - Estimates of parameters of logistic equation for females and males of Buenia affinis from the Kvarner area ( $\mathrm{r}^{2}$ coefficient of determination, SE standard error). $\mathrm{b}=$ length at sexual maturity $\left(\mathrm{L}_{50}\right)$.

\begin{tabular}{lcccc}
\hline Parameter & \multicolumn{2}{c}{ Females } & \multicolumn{2}{c}{ Males } \\
& Estimate & SE & Estimate & SE \\
\hline a & 0.60 & 0.02 & 0.77 & 0.05 \\
$\mathrm{~b}$ & 26.10 & 0.07 & 27.36 & 0.10 \\
$\mathrm{r}^{2}$ & 0.99 & & 0.99 & \\
\hline
\end{tabular}

determine the presence of seasonal growth bands (annuli). Von Bertalanffy growth parameters $\left(\mathrm{L}_{\infty}, \mathrm{k}\right.$ and $\left.\mathrm{t}_{0}\right)$ were calculated from length-frequency data recorded monthly, using the ELEFAN I routine (Pauly and David, 1981) within the FISAT II software package. Finally, the growth performance index $\left(\Phi^{\prime}=2 \log \mathrm{L}_{\infty}\right.$ $+\log$ k) (Munro and Pauly, 1983) was employed to compare growth of $B$. affinis with that of other gobies.

\section{RESULTS}

\section{Sex ratio}

All 240 specimens of $B$. affinis were sexed successfully, resulting in 112 females and 128 males. The overall ratio of females to males was $1: 1.14$, not differing significantly from $1: 1\left(\chi^{2}=1.07\right.$, d.f. $\left.=1, \mathrm{P}>0.1\right)$.

\section{Length at sexual maturity}

The size of the smallest female and male in any of the mature stages (i.e. II-V) was $24.4 \mathrm{~mm}$ and 25.2 $\mathrm{mm}$, respectively. The length at sexual maturity $\left(\mathrm{L}_{50}\right)$ was estimated from 112 females and 128 males ranging from 13.6 to $38.3 \mathrm{~mm}$ and 12.5 to $36.6 \mathrm{~mm}$. Length at sexual maturity was estimated to be 26.1 and 27.4 $\mathrm{mm}$ in females and males, respectively (Table 1).

\section{Annual cycle of gonad development and spawning period}

The number of fish in each maturity stage collected during the sampling period is summarized in Table 2. Interestingly, individuals with completely spent gonads (sensu Miller, 1961, stage V) were never found during the year. Juveniles (i.e. immature individuals, stage I) were caught almost all year round, though they were more abundant in summer-early autumn (JulyOctober). Gonad development in both sexes started in autumn, with the appearance of individuals in stage II (i.e. developing virgin and recovering spent), some of them being rarely collected until spring. Ripening females and males (stage III) were present throughout the entire winter and spring, whereas ripe fish (stage IV) were collected from February to July. The temporal shift of different gonad maturity stages (i.e. the annual cycle of gonad development) is evident (Table 2). Female gonadosomatic index (GSI) (Fig. 2a) varied significantly across months $(\mathrm{H}$ Kruskal-Wallis $=73.6$, 
TABLE 2. - Specimens of Buenia affinis from the Kvarner area in each maturity stages by month of sampling: I, immature; II, developing virgin and recovering spent; III, ripening (for females IIIa = early ripening and IIIb = late ripening); IV, ripe; V, spent. In parentheses: number of females and males of maturity stages II-IV in proportion to total number of mature females and males for each month.

\begin{tabular}{|c|c|c|c|c|c|c|}
\hline \multirow[b]{2}{*}{ Females } & \multirow[b]{2}{*}{ I } & \multicolumn{3}{|c|}{ Maturity stages } & \multirow[b]{2}{*}{ IV } & \\
\hline & & II & III'a & IIIb & & $\mathrm{V}$ \\
\hline May 2003 & & $4(44.4 \%)$ & $1(11.1 \%)$ & $3(33.3 \%)$ & $1(11.1 \%)$ & \\
\hline Jun 2003 & 3 & $1(20 \%)$ & & - & $4(80 \%)$ & \\
\hline Jul 2003 & 4 & -- & $2(50 \%)$ & - & $2(50 \%)$ & . \\
\hline Aug 2003 & 12 & - & - & - & - & \\
\hline Sep 2003 & 10 & - & - & - & - & \\
\hline Oct 2003 & 6 & $1(100 \%)$ & - & - & - & \\
\hline Nov 2003 & 7 & $5(100 \%)$ & - & - & - & \\
\hline Dec 2003 & 3 & $6(85.7 \%)$ & - & $1(14.3 \%)$ & - & \\
\hline Jan 2004 & - & $8(61.5 \%)$ & $1(7.7 \%)$ & $3(23.1 \%)$ & $1(7.7 \%)$ & \\
\hline Feb 2004 & - & $1(10 \%)$ & $3(30 \%)$ & $3(30 \%)$ & $3(30 \%)$ & \\
\hline Mar 2004 & - & $1(12.5 \%)$ & - & $1(12.5 \%)$ & $6(75 \%)$ & \\
\hline Apr 2004 & 1 & $2(50 \%)$ & - & $1(25 \%)$ & $1(25 \%)$ & \\
\hline Males & I & II & III & IV & V & \\
\hline May 2003 & 1 & - & $1(10 \%)$ & $9(90 \%)$ & - & \\
\hline Jun 2003 & 3 & - & $1(11.1 \%)$ & $8(88.9 \%)$ & - & \\
\hline Jul 2003 & 9 & - & - & $3(100 \%)$ & - & \\
\hline Aug 2003 & 8 & - & - & - & - & \\
\hline Sep 2003 & 10 & - & - & - & - & \\
\hline Oct 2003 & 13 & - & - & - & - & \\
\hline Nov 2003 & 4 & $4(100 \%)$ & - & - & - & \\
\hline Dec 2003 & 4 & $5(83.3 \%)$ & $1(16.7 \%)$ & - & - & \\
\hline Jan 2004 & 2 & $2(40 \%)$ & $3(60 \%)$ & - & - & \\
\hline Feb 2004 & - & $4(44.4 \%)$ & $4(44.4 \%)$ & $1(11.1 \%)$ & - & \\
\hline Mar 2004 & - & $1(7.7 \%)$ & $7(53.8 \%)$ & $5(38.5 \%)$ & - & \\
\hline Apr 2004 & 2 & - & $8(61.5 \%)$ & $5(38.5 \%)$ & - & \\
\hline
\end{tabular}

$\mathrm{P}<0.001)$, as did male gonadosomatic index (GSI) $(\mathrm{H}$ Kruskal-Wallis $=95.4, \mathrm{P}<0.001)$ and seminal-vesiclesomatic index (SVSI) (H Kruskal-Wallis $=78.4$, $\mathrm{P}<0.001$ ) (Figs $2 \mathrm{~b}$ and 2c). The increase in GSI of both sexes and male SVSI started slowly with the beginning of winter, followed by a steadier increase and high values from February to June (females) and May (males). In males, GSI $(0.32 \pm 0.04)$ and SVSI $(0.13 \pm 0.02)$

(a)

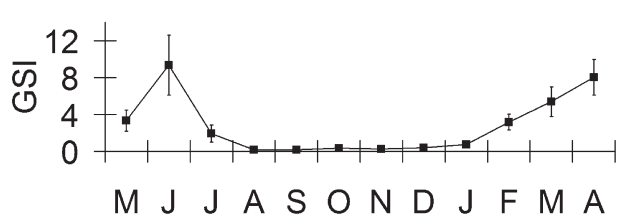

(c)

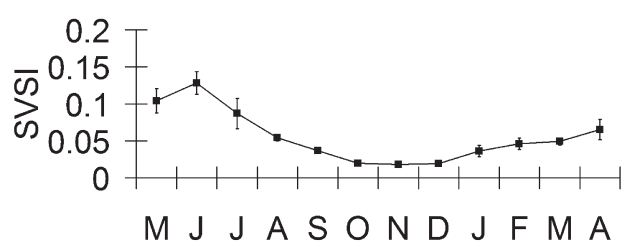

TABLE 3. - Analysis of variance of the hepatosomatic index (HSI) of Buenia affinis from the Kvarner area versus sex and month.

\begin{tabular}{lcccc}
\hline Source of variation & d.f. & MS & F & $P$ \\
\hline Sex & 1 & 8.85 & 10.72 & 0.001 \\
Month & 11 & 9.83 & 11.90 & $<0.001$ \\
Sex * month & 11 & 1.22 & 1.48 & 0.14 \\
\hline
\end{tabular}

peaked in May and June, respectively. In females, GSI had two monthly peaks, in April (GSI= 8.02 \pm 1.93 ) and June $(\mathrm{GSI}=9.36 \pm 3.25)$. The lowest GSI value recorded in May was probably due to the presence of only one ripe female in the monthly sample (see Table 2). The GSI values of both sexes were again low in August. Considering the monthly pattern of gonad indices in both sexes, as well as the presence of ripe females and males, the spawning season was spread over a rather long period, lasting from February to July (Table 2 and Fig. 2), in concomitance with the increase in sea water temperature (Table 2 and Fig. 2).

\section{Hepatosomatic index}

Females had a significantly higher hepatosomatic index (HSI) than males, without seasonal interaction (Table 3). HSI of both sexes showed a clear seasonal pattern, with significant variation across months (Table 3 and Fig. 3). A steady increase in HSI in both sexes occurred in early winter. In both sexes HSI peaked in February, decreasing thereafter during the spawning season (Fig. 3).

\section{Egg size and fecundity}

Based on the egg size pattern observed within the ovarian stroma of gravid females, ovaries of $B$. affinis exhibited a group-synchronous development (Wallace and Selman, 1981), as two main groups of oocytes

(b)

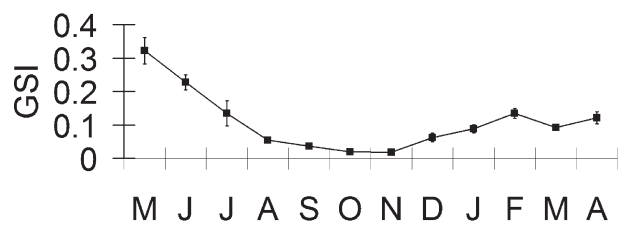

(d)

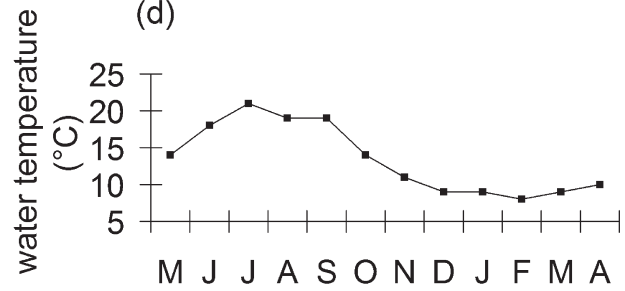

FIG. 2. - Mean ( \pm standard error) monthly gonadosomatic index (GSI) of (a) female and (b) male and the seminal-vesicle-somatic index (SVSI) (c) of Buenia affinis from the Kvarner area. Mean monthly sea temperature at the collecting depth is also given (d). 

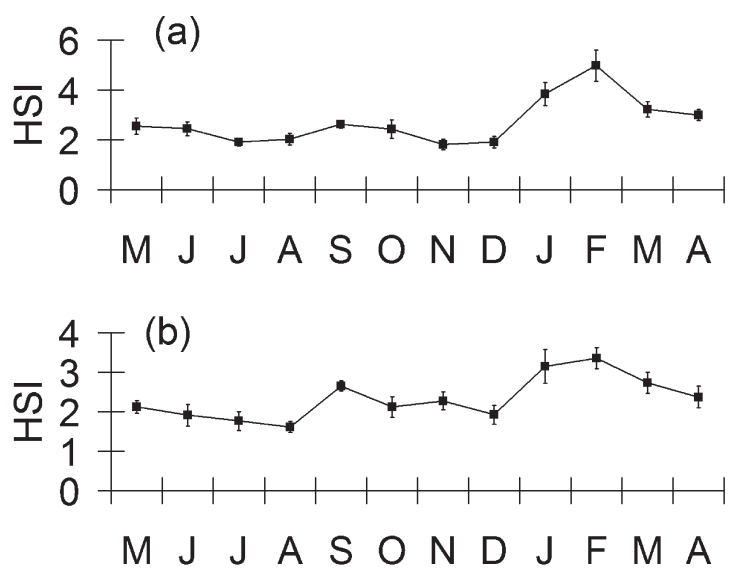

FIG. 3. - Mean ( \pm standard error) monthly hepatosomatic index (HSI) of (a) female and (b) male of Buenia affinis from the Kvarner area.

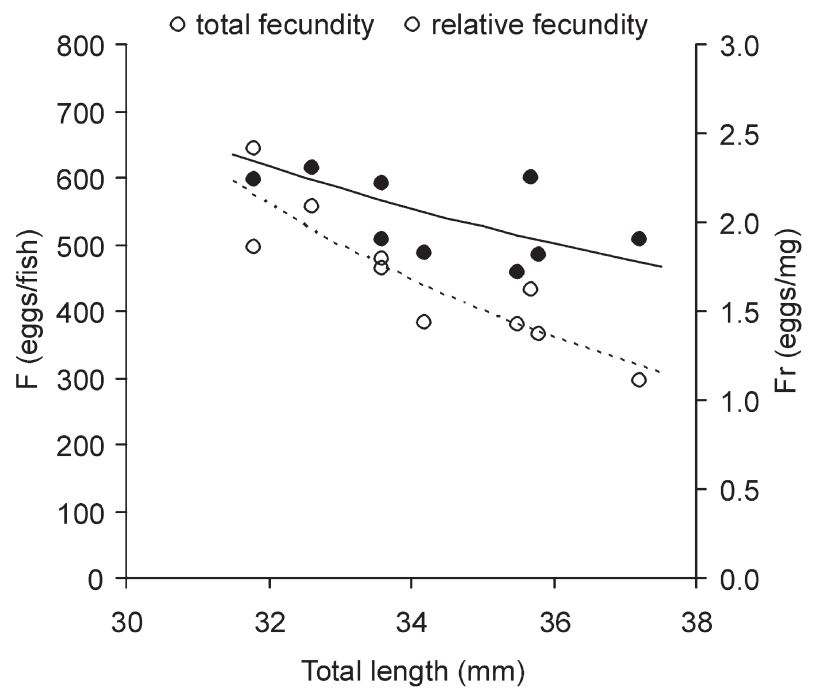

FIG. 4. - Plot of absolute fecundity and relative fecundity against total length of Buenia affinis from the Kvarner area.

were easily distinguished by size: a fairly synchronous group of oocytes as large as $0.4-0.6 \mathrm{~mm}$, which represented the clutch to be spawned in the current spawning season, and a more heterogeneous group of oocytes smaller than $0.16 \mathrm{~mm}$, which could be spawned in a further spawning season.

Fecundity was estimated from 10 gravid females ranging between 31.8 and $37.2 \mathrm{~mm}$ TL. The absolute fecundity $(\mathrm{F})$ ranged from 457 to 714 eggs per individual (mean $\pm \mathrm{SE}, 556 \pm 25)$, whereas the relative fecundity (Fr) ranged from 1.1 to $2.4 \mathrm{eggs} / \mathrm{mg}$ (mean $\pm \mathrm{SE}, 1.7 \pm 0.1)$ (Fig. 4). A negative relationship was found between absolute/relative fecundity and fish size, as summarized in the following equations:

$$
\begin{aligned}
F & =291925 \mathrm{TL}^{-1.78}\left(\mathrm{n}=10, \mathrm{r}^{2}=0.46\right) \\
\mathrm{Fr} & =1030861 \mathrm{TL}^{-3.78}\left(\mathrm{n}=10, \mathrm{r}^{2}=0.81\right)
\end{aligned}
$$

The high individual variability of absolute fecun- dity found in fish of comparable size was responsible for the poor fit between $\mathrm{F}$ and TL, which explained only $46 \%$ of total variance.

\section{Growth rate and recruitment}

Monthly length frequency distribution of fish samples is summarized in Figure 5. Roughly, two main cohorts of different size occurred from April to July. Afterwards, the larger/older cohort totally disappeared, and the single smaller surviving cohort grew up from August until the next spring-summer season. The peak of recruitment of $B$. affinis to the demersal adult population took place in June consisting of juveniles from 12 to $15 \mathrm{~mm} \mathrm{TL}$, in good agreement with previous data on reproductive cycle (see above). Following the modal progression of the length-frequency distribution of a single cohort (Fig. 6), we estimated the Von Bertalanffy growth parameters reported below:

$$
\mathrm{L}_{\infty}=40.95, \mathrm{k}=1.50, \Phi^{\prime}=3.40
$$

where $\mathrm{L}_{\infty}$ is the asymptotic length, $\mathrm{k}$ is the instantaneous growth rate and $\Phi$ ' the growth performance index. Furthermore, based on the length frequency distribution pattern observed throughout the year and the seasonal growth bands on sagittal otoliths, it could be hypothesized that $B$. affinis is an annual species. On all checked sagittal otoliths the annulation pattern consisted of an opaque nucleus followed by a single wide translucent band and a single narrow opaque band close to the margin (Fig. 7), providing circumstantial evidence of the absence of fish older than one year in the population sampled.

\section{DISCUSSION}

The present study provides the first data on the reproduction and growth of Buenia affinis. This is one of the few very small benthic gobies (TL $<5 \mathrm{~cm}$ ) of the northeastern Atlantic and Mediterranean Seas whose life history is known (Miller, 1986; Rogers, 1989; Fouda et al., 1993; Pampoulie and Bouchereau, 1996; Bouchereau and Guelorget, 1998; Pampoulie et al., 2000; Mazzoldi and Rasotto, 2001; Bouchereau, 2002). It could be expected that body miniaturization in these fishes results in adaptive changes of life strategies in comparison with their relatives of larger size (Miller, 1979). B. affinis is an epibenthic species living on sandy bottoms, where the high risk of predation probably influences its life history traits. Numerous SCUBA dives in the Kvarner area confirmed that this species was present all year around only on the infralittoral clear coarse to medium sands, so migration of older and large-sized specimens elsewhere can be excluded (Kovačić, 2002). Therefore, the present study indicates that $B$. affinis is an annual species, with an early maturation and a protracted spawning season from February to July. Body growth is high in the first summer and 

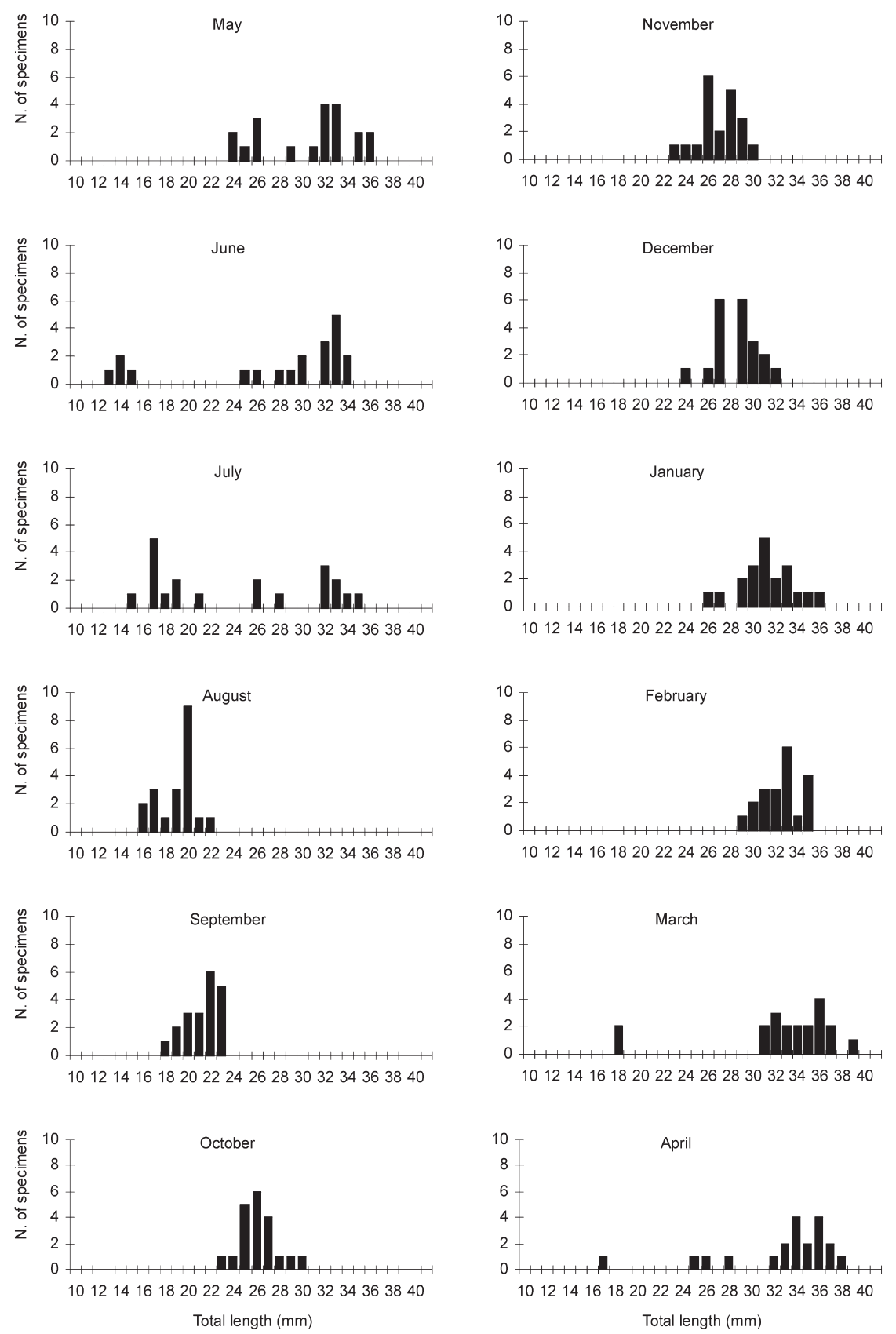

FIG. 5. - Monthly length frequency distributions of Buenia affinis collected in the Kvarner area.

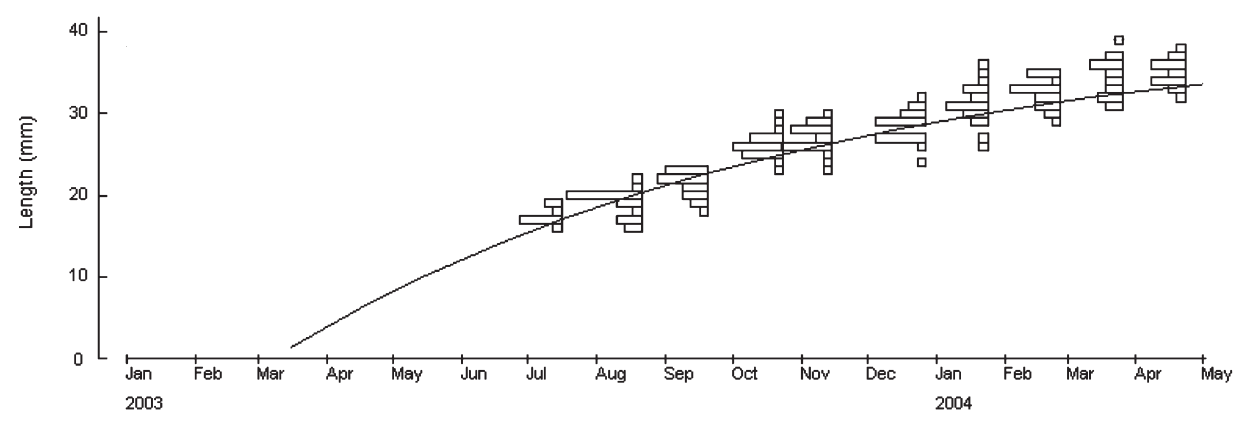

FIG. 6. - Von Bertalanffy growth curve fitted to monthly length frequency distributions of a single Buenia affinis cohort. 


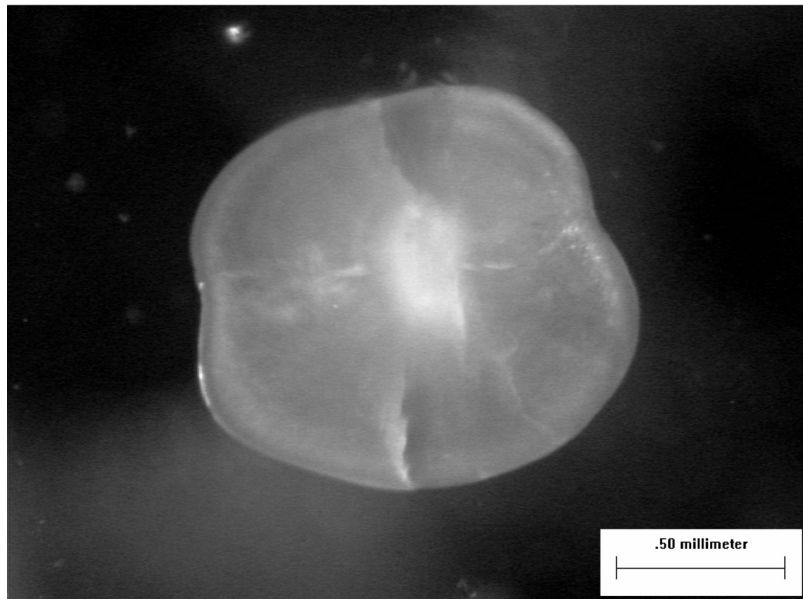

FIG. 7. - Sagittal otolith of Buenia affinis male caught in June (32.2 $\mathrm{mm}$ TL), consisting of an opaque nucleus surrounded by a wide translucent band and a rather narrow opaque band close to the margin, both forming one annulus.

autumn (Figs 5 and 6), followed by a steady gonad development in winter until spawning (Fig. 2). The presence of two main groups of oocytes in ripe ovaries indicates that each female could spawn more than once during the life cycle. This type of reproduction, known as abbreviate iteroparity and characterized by a long reproductive season with several spawning events by each individual in a short lifespan, is common in several species of small gobiids such as Pomatoschistus (Miller, 1961; Bouchereau et al., 1989; Fouda et al., 1993), Knipowitschia and Economidichtys (Daoulas et al., 1993) and Aphia (Caputo et al., 2000).

The absence of the specimens in the spent stage (V) in the sample and the disappearance of the older cohort after the spawning season could be due to high mortality of the post-spawning individuals. The reduction of liver mass during the spawning season could reflect the spending of stored energy for the high-energy-demanding process of late gonad development. The highest value of HSI of both sexes at the beginning of the spawning season and its further decrease was also observed in another small goby inhabiting the same area, Gobius vittatus Vinciguerra, 1883 (Kovačić, 2007).

The life history strategy of $B$. affinis can be compared with that of other epibenthic small gobies sharing the same habitat, such as Pomatoschistus microps (Krøyer, 1838), P. marmoratus (Risso, 1810), P. norvegicus (Collett, 1903) and P. pictus (Malm, 1865) (Gibson and Ezzi, 1981; Collins, 1982; Bouchereau and Guelorget, 1998; Mazzoldi and Rasotto, 2001). The life history traits of $P$. pictus and $P$. marmoratus closely resemble those of $B$. affinis. They are all annual species with a common life cycle, consisting initially of a high body growth rate during the first summer and autumn after hatching. This is followed by a steady gonad development in winter, with an early maturation and a protracted spawning season from spring to early summer and, after a single spawning season in the lifetime, a high mortality of post-spawning specimens (Collins, 1982; Mazzoldi and Rasotto, 2001). However, in $P$. pictus, a few specimens in the population survived after spawning and reached two years of age (females 20-24 months, males 25-29 months) (Collins, 1982). The first recruitment of juveniles $P$. pictus and $P$. marmoratus to the adult population was recorded in July, while the first juveniles of $B$. affinis recruited already in April. In P. marmoratus, a second spawning peak was observed in August-September, consisting of a few very small breeders of both sexes (Mazzoldi and Rasotto, 2001). It was assumed that such individuals hatched in the first spawning peak, contrary to most of the population, which reach sexual maturity in the same summer and give rise to the following AugustSeptember spawning peak. The life-history strategy of $P$. microps differs between the Mediterranean and the northeastern Atlantic populations (Bouchereau and Guelorget, 1998). While the life-history traits of the population from the Mauguio lagoon (Mediterranean) are similar to those of $B$. affinis, $P$. pictus and $P$. marmoratus, the Atlantic population exhibits larger size (64 mm), longer lifespan (two years), and a second spawning event during the lifetime at an age of 20-24 months. On the other hand, the $P$. microps population from the Mauguio lagoon attains sexual maturity and spawns before the first winter as $P$. marmoratus, at about 4-5 months of age (Bouchereau and Guelorget, 1998). Compared with the aforementioned small epibenthic species, $P$. norvegicus lives longer, and a significant part of the population breed in the second season and die at the beginning of the third year on the west coast of Scotland (Gibson and Ezzi, 1981). Hence, it seems that the lower temperature at higher latitudes or greater depths positively affects longevity of very small epibenthic gobies.

In the pelagic habitat, the risk for survival due to predation is potentially even greater than in the open bottom conditions (Miller, 1996). Consequently, the pelagic northeastern Atlantic and Mediterranean gobies, such as Aphia minuta (Risso, 1810) and Crystallogobius linearis (von Düben, 1845), share with the very small epibenthic species the same life history strategies: short (annual) lifespan, rapid maturation, high reproductive effort and energetic investment for reproduction, and long spawning season (Caputo et al., 2003; La Mesa et al., 2005). In pelagic gobiids, adaptation to pelagic life has been achieved by progenesis, a type of heterochrony where ontogeny is truncated by accelerated gonad maturation. Similarly, most of paedomorphic gobiids exhibit a sudden death of breeders soon after spawning (La Mesa, 2010).

In conclusion, despite the enormous adaptive radiation of gobiids in terms of both fish size and life styles, a common evolutionary trend towards a "simplification" of life history seems to characterize gobiids sharing body miniaturization but inhabiting the very different epibenthic and pelagic habitats. 


\section{ACKNOWLEDGMENTS}

M. Kovačić was supported in part by the Ministry of Science, Education and Sports of the Republic of Croatia (Grants No. 119-1782739-1233 and 001-0013077-0844).

\section{REFERENCES}

Bouchereau, J.-L. - 2002. First data on the demography and growth of Millerigobius macrocephalus (Kolombatović, 1891) (Teleostei; Gobiidae), in Corsica (France). Acta Adriat. 43: 77-85.

Bouchereau, J.-L. and O. Guelorget. - 1998. Comparison of three Gobiidae (Teleostei) life history strategies over their geographical range. Oceanol. Acta, 21: 503-517.

Bouchereau, J.-L., J.C. Joyeux, J.A. Tomasini and J.P. Quignard. 1989. Cycle sexuel, fécondité et condition de Pomatoschistus microps (Kroier, 1838) (Gobiidés) dans la lagune de Maguio, France. Bull. Ecol., 20: 193-202.

Caputo, V., G. Candi, M. La Mesa and E. Arneri. - 2000. Pattern of gonad maturation and the question of semelparity 106 in the paedomorphic goby Aphia minuta. J. Fish Biol., 58: 656-669.

Caputo, V., M. La Mesa, G. Candi and P.N. Cerioni. - 2003. The reproductive biology of the crystal goby with a comparison to that of the transparent goby. J. Fish Biol., 62: 375-385.

Collins, S.P. - 1982. Littoral and benthic investigations on the west coast of Ireland - XIV. The biology of the painted goby, Pomatoscistus pictus (Malm) on the Connemara coast. Proc. Roy. Irish Acad., 82: 21-37.

Daoulas, C., A.N. Economou, T. Psarras and R. Barbieri-Tseliki. 1993. Reproductive strategies and early development of three freshwater gobies. J. Fish Biol., 42: 749-776.

Fage, L. - 1918. Shore-fishes. Rep. Dan. oceanogr. Exped. Med., 2(A.3): 1-154.

Fouda, M.M., M.Y. Hanna and F.M. Fouda. - 1993. Reproductive biology of the Red Sea goby, Silhouettea aegyptia, and a Mediterranean goby, Pomatoschistus marmoratus, in Lake Timsah, Suez Canal. J. Fish Biol., 43: 139-151.

Gibson, R.N. and I.A. Ezzi. - 1981. The biology of Norway goby, Pomatoschistus norvegicus (Collett), on the west coast of Scotland. J. Fish Biol., 19: 697-714.

Kartas, F. and J.P. Quignard. - 1984. La fécondité des poissons téléostéens. Masson, Paris.

Kovačić, M. - 2001. The biology of Roule's goby in the Kvarner area, northern Adriatic Sea. J. Fish Biol., 59: 795-809.

Kovačić, M. - 2002. A northern Adriatic population of Buenia affinis (Gobiidae). Cybium, 26: 197-201.

Kovačić, M. - 2007. Reproductive biology of the striped goby, Gobius vittatus (Gobiidae) in the northern Adriatic Sea. Sci. Mar., 71: 145-151.

Kovačić, M. and M. La Mesa. - 2008. Feeding ecology of De Buen's goby in the Adriatic Sea. Vie Milieu, 58: 249-256.

Kovačić, M. and R.A. Patzner. - 2009. Reidentification of Buenia specimens (Gobiidae) from Banyuls-sur-Mer (France, western Mediterranean). Cybium, 33: 175-176.

Kovačić, M. and R.A. Patzner. - 2010. North-Eastern Atlantic and Mediterranean gobies. In: R.A. Patzner, J.L. Van Tassell, M. Kovačić and B.G. Kapoor (eds.), The Biology of Gobies. Science Publisher Inc., Enfield, in press.

La Mesa, M. - 2010. Planktonic and paedomorphic gobioids. In: R.A. Patzner, J.L. Van Tassell, M. Kovačić and B.G. Kapoor (eds.), The Biology of Gobies. Science Publisher Inc., Enfield, in press.
La Mesa, M., E. Arneri, V. Caputo and M. Iglesias. - 2005. The transparent goby, Aphia minuta: review of biology and fisheries of a paedomorphic European fish. Rev. Fish Biol. Fisher., 15: 89-109.

Mazzoldi, C. and M.B. Rasotto. - 2001. Extended breeding season in the marbled goby, Pomatoschistus marmoratus (Teleostei: Gobiidae), in the Venetian Lagoon. Environ. Biol. Fish., 61: 175-183.

Miller, P.J. - 1961. Age, growth, and reproduction of the rock goby Gobius paganellus L., in the Isle of Man. J. Mar. Biol. Ass. U.K., 41: 737-769.

Miller, P.J. - 1979. Adaptiveness and implications of small size in teleosts. Symp. Zool. Soc. Lond., 44: 263-306.

Miller, P.J. - 1984. The tokology of gobioid fishes. In: G.W. Potts and R.J. Wootton (eds.), Fish reproduction: strategies and tactics, pp. 118-153. Academic Press, New York.

Miller, P.J. - 1986. Gobiidae. In: P.J.P. Whitehead, M.-L. Bauchot, J.-C. Hureau, J. Nielsen and E. Tortonese, (eds.), Fishes of the North-eastern Atlantic and the Mediterranean, Vol. III, pp. 1019-1085. UNESCO, Paris.

Miller, P.J. - 1996. The functional ecology of small fish: some opportunities and consequences. Symp. Zool. Soc. London., 69: 175-199.

Munro, J.L. and D. Pauly. - 1983. A simple method for comparing the growth of fishes and invertebrates. ICLARM Fishbyte, 1: $5-6$.

Pampoulie, C. and J.-L. Bouchereau. - 1996. Elements de systematique et de biologie de deux gobiides (poissons teleosteens), Chromogobius quadrivittatus (Steindachner, 1863) et Chromogobius zebratus zebratus (Kolombatović, 1891), des Bouches de Bonifacio (Corse, France). Ichthyo-Physiol. Acta, 19: $153-178$.

Pampoulie, C., J.-L. Bouchereau, E. Rosecchi, G. Poiza and A.J. Crivelli. - 2000. Annual variations in the reproductive traits of Pomatoschistus microps in a Mediterranean lagoon undergoing environmental changes: evidence of phenotypic plasticity. $J$. Fish Biol., 57: 1441-1452.

Patzner, R.A., M. Seiwald, S. Angerer, E.A. Ferrero and P.G Giulianini. - 1991. Genital system and reproductive cycle of the male grass goby, Zosterisessor ophiocephalus (Teleostei, Gobiidae) in the Northern Adriatic Sea. Zool. Anz., 226(5/6): 205-219.

Pauly, D. and N. David - 1981. ELEFAN I, a BASIC program for the objective extraction of growth parameters from lengthfrequency data. Meeresforsch., 28: 205-211.

Rogers, S.I. - 1989. Seasonal variations in fecundity and egg size of the common goby, Pomatoschistus microps. J. Mar. Biol. Ass. U.K., 69: 535-543.

Sanzo, L. - 1911. Distribuzione delle papille cutanee (organi ciatiforme) e suo valore sistematico nei Gobi. Mitt. Zool. Stat. Neapel, 20: 249-328.

Sokal, R.R. and F.J. Rohlf. - 1995. Biometry. W.H. Freeman and company, New York.

Wallace, R.A. and K. Selman. - 1981. Cellular and dynamic aspects of oocyte growth in teleosts. Amer. Zool., 21: 325-343.

Zander, C.D. - 1982. Zur Morphologie und Biologie einiger seltener Grundeln des Mittelmeeres (Pisces, Gobioidei, Gobiidae). Senckenb. Marit., 14: 1-8.

Zander, C.D. and J. Berg. - 1984. Feeding ecology of littoral gobiid and blennioid fishes of the Banyuls area (Mediterranean Sea) II. Prey selection and size preference. Vie Milieu, 34: 149-157.

Scient. ed.: A. Garcia-Rubies.

Received July 10, 2009. Accepted December 12, 2009

Published online May 28, 2010. 